\title{
Kebijakan Komunikasi Internasional Indonesia
}

\section{(International Communications Policy Indonesia)}

\author{
Daryanto Setiawan* \\ Ilmu Komunikasi, Fakultas Ilmu Sosial dan Ilmu Politik \\ Universitas Muhammadiyah Sumatera Utara, Indonesia \\ *E-mail: daryantosetiawannew@gmail.com
}

\begin{abstract}
Abstrak
Kebijakan komunikasi merupakan bagian yang terintegrasi dengan kebijakan pembangunan lainnya, seperti halnya pendidikan, kebudayaan, dan kependudukan. Komunikasi dapat memberikan kontribusinya dalam mendukung pelaksanaan program-program pembangunan nasional di setiap negara. Konsep kebijakan komunikasi internasional baru muncul pada tahun 1970-an setelah para pakar dari negara-negara yang sedang berkembang mengeluhkan adanya ketidakseimbangan dan tidak berkadilan dari negara-negara maju mengenai pengaliran informasi di dunia. Negara-negara maju tersebut cenderung memberitakan hal-hal yang berkaitan dengan kerusuhan dan kemiskinan yang terjadi di negara-negara yang berkembang. Ketidakseimbangan pengaliran informasi dari negaranegara maju ke negara-negara yang berkembang membuat negara-negara yang bekembang kurang mampu untuk membeli teknologi informasi. Akhirnya negara-negara berkembang merespon kejadian tersebut. Berdasarkan Pancasila sila kedua, UUD 1945 (Alinea I dan IV) dan batang tubuh (pasal 11 dan 13), Indonesia sebagai salah satu negara berkembang akhirnya juga merespon kejadian tersebut dengan ikut terlibat langsung dalam hubungan internasiona melalui kebijakan politik luar negeri Indonesia yang bebas dan aktif. Bebas, bahwa Indonesia tidak memihak pada kekuatan-kekuatan yang tidak sesuai dengan kepribadian bangsa sebagaimana tercermin dalam Pancasila. Aktif, bahwa dalam menjalankan kebijakan luar negerinya, Indonesia tidak bersikap pasif atas berbagai kejadian internasional, melainkan bersikaf aktif. Juga aktif dalam mendukung usaha-usaha yang diarahkan bagi terciptanya masyarakat dunia yang damai, aman dan tentram.
\end{abstract}

Kata Kunci: Kebijakan; Komunikasi Internasional; Indonesia.

\begin{abstract}
Communication policy is the part that is integrated with other development policies, such as education, culture, and population. Communication can give its contribution in support of the implementation of national development programmes in each country. The concept of a new international communication policy emerged in 1970s after experts from the countries that complained about the growing presence of imbalance and not berkadilan from developed countries about the stream of information in the world. The advanced countries tend to preach the things related to the poverty and unrest that occurred in developing countries. An imbalance of information streaming from the developed countries to the developing countries that make countries less able to bekembang to buy information technology. Eventually developing countries respond to the incident. Based on Pancasila, the 1945 constitution second sila (Paragraph I and IV) and torso (article 11 and 13), Indonesia as one of the developing world eventually respond to the incident by get involved directly in internasiona relations through policies Indonesia's foreign politics that are free and active. Free, that Indonesia is not impartial on forces that are not in accordance with the personality of the nation as reflected in the Pancasila. Active, that in carrying out its foreign policy, Indonesia is not being passivity over a range of international events, but rather an active bersikaf. Also active in support of the efforts geared to the creation of a peaceful world community, safe and peaceful.
\end{abstract}

Keywords: Policy; International Communication; Indonesian.

How to cite: Setiawan, D., (2017), Kebijakan Komunikasi Internasional Indonesia, SIMBOLIKA, 3 (1), 2233. 


\section{PENDAHULUAN}

Konsep kebijakan komunikasi internasional baru muncul pada tahun 1970-an setelah para pakar dari negaranegara yang sedang berkembang mengeluhkan adanya ketidakseimbangan dan tidak berkadilan dari negara-negara maju mengenai pengaliran informasi di dunia. Akibat ketidak-seimbangan pengaliran informasi dari negara-negara maju ke negara-negara yang sedang berkembang membuat negara-negara yang sedang bekembang kurang mampu untuk membeli teknologi informasi.

Ketidakseimbangan informasi ini didukung oleh hasil hasil riset Gebner (Dean, Annenberg School of Communication) terhadap isi enam puluh surat kabar yang terbit di Sembilan negara, yakni tiga negara kapitalis (Amerika Serikat, Inggris, dan Jerman Barat), tiga negara sosialis (Uni Soviet = sekarang Rusia, Hongaria, Cekoslawakia), dan tiga negara sedang berkembang (India, Filipina, dan Ghana). Dari hasil analisis ke-60 surat kabar tersebut menunjukkan bahwa surat-surat kabar yang terbit di negara-negara kapitalis dan negara-negara sosialis terlalu sedikit mengekspos tentang berita-berita di negara berkembang. Kalau toh surat kabar itu memberitakan, maka cenderung hanya hal-hal yang berkaitan dengan kerusuhan dan kemiskinan (Cangara, 2013:5).

Di Indonesia, kebijaksanaan komunikasi secara implisit dapat dilihat pada nilai-nilai yang tumbuh dan dianut oleh masing-masing anggota masyarakat dari suatu suku yang memperlakukan aturan itu meski tidak dalam bentuk tertulis. Sedangkan secara ekplisit, kebijaksanaan komunikasi di Indonesia dapat dilihat dapat dilihat dengan adanya berbagai undang-undang atau peraturan yang telah dikeluarkan oleh pemerintah untuk ditaati bagi setiap warga Negara (Cangara, 2013:12).

Pengertian kebijakan komunikasi berhasil dirumuskan olah beberapa pakar (Cangara, 2013:12), di antaranya: Soomerland (1975): Kebijaksanaan komunikasi adalah prinsip-prinsip, atuaran-aturan, dan pedoman di mana sistem komunikasi dibangun secara khusus dalam kerangka yang lebih luas. Sean McBraid, mengatakan bahwa kebijaksanaan komunikasi adalah prinsipprinsip, aturan-aturan, atas pedoman di mana sistem komunikasi dibangun sehingga menjadi kerangka kerja yang dapat digunakan untuk mengordinasikan kegiatan, memilih pendekatan dengan melihat kemungkinan alokasi dana, keputusan-keputusan struktural yang berpengaruh terhadap aktivitas komunikasi, serta berusaha menyisihkan ketidakseimbangan faktor-faktor eksternal dan internal, serta menetapkan prioritas yang akan diambil.

Allan Hancock

"Kebijaksanaan komunikasi adalah perencanaan strategik yang menetapkan alternatif dalam mencapai tujuan jangka panjang, serta menjadi kerangka dasar untuk perencanaan operasional jangka pendek, perencanaan strategik diwujudkan dalam target yang dapat dikuantifikasi dengan pendekatanpendekatan yang sistematis terhadap tujuan yang ingin dicapai dari kebijaksanaan-kebijaksanaan komunikasi.

UNESCO (1978), kebijaksanaan komunikasi adalah kumpulan dari prinsipprinsip dan norma-norma yang dibuat dan 
disusun untuk memberikan pedoman terhadap perilaku sistem-sistem komunikasi. Ia berasal dari ideologiideologi politik, sosial, ekonomi, budaya, kondisi-kondisi legal dan nilai-nilai dari suatu bangsa atau negara dengan berusaha mengaitkan kebutuhan nyata, dan kesepakatan-kesempatan yang bakal ada dalam bidang komunikasi.

SM Ali, seorang konsultan komunikasi yang bekerja di UNESCO yang berkedudukan di Bangkok mulai mempertanyakan mengenai kebijakan komunikasi. Hal ini berdasarkan analisisnya yaitu jika suatu negara memiliki suatu kebijaksanaan pendidikan dan kebudayaan, serta kebijaksanaan dalam moneter dan finansial misalnya, maka kebijakan komunikasi harus ada.

SM Ali lebih jauh melihat bahwa kebijakan komunikasi tidak lepas dari bagian kebijakan nasional, bahkan kebijakan komunikasi merupakan bagian yang terintegrasi dengan kebijakan pembangunan lainnya, seperti halnya pendidikan, kebudayaan, dan kependudukan. Komunikasi dapat memberikan kontribusinya dalam mendukung pelaksanaan programprogram pembangunan nasional di setiap negara. Komunikasi sebagai sumber daya sama pentingnya dengan sektor-sektor lain di dalam pembangunan bangsa, bahkan kebijakan nasional yang dibangun diatas kebijakan sektoral juga tidak lepas dari kebijakan dan perencanaan komunikasi (Cangara, 2013:10).

Ely D. Gomez juga seorang konsultan komunikasi UNESCO yang berasal dari Afganistan juga menyebutkan bahwa komunikasi sebagai sumber daya harus diberi kedudukan yang sama dengan sumber daya pembangunan lainnya dalam penetepan kebijakan suatu negara. Gomez lebih jauh melihat bahwa komunikasi memiliki potensi yang sangat vital dalam pengembangan tugas-tugas dalam perubahan sosial, terutama dalam mendorong percepatan proses alih teknologi dan upaya peningkatan partisipasi masyarakat.

$$
\text { Pertimbangan lain perlunya }
$$
disususun kebijakan komunikasi oleh suatu negara, menurut Sean McBride (Cangara, 2013: 10) adalah sebagai berikut, pertama, aktivitas komunikasi yang makin rumit akibat kemajuan teknologi terutama dalam bidang teknologi komunikasi satelit. Dari aspek global, ekspansi komunikasi internasional makin mengaburkan batas-batas negara. Oleh karena itu, kebijaksanaan komunikasi perlu diformulasi untuk mengantisipasi dan menyesuaikan diri dengan perkembangan regulasi internasional. Ini dimaksudkan agar negara tidak mengalami ketertinggalan teknologi dan regulasi. Konvergensi teknologi infomasi telah menimbulkan arah baru dalam industry media dengan munculnya tekonologi multimedia. Hal ini perlu diantisipasi kemungkinan akan timbulnya kompetisi di kalangan penyedia jasa informasi yang bisa mengarah pada hal negatif tanpa penegakan etika, serta perlunya dilakukan peningkatan profesionalisme di kalangan para pekerja informasi.

Kedua adalah penggunaan sumber daya komunikasi yang tidak efisien, makin tajamnya kesenjangan informasi yang dimiliki atara kalangan elite dan non-elite, atara penduduk yang mayoritas dengan minoritas, atara kota dan desa, antara 
yang miskin dan kaya, atara pintar dan yang bodoh. Adanya kegagalan-kegagalan yang terjadi dalam berbagai proyek komunikasi dalam bentuk infrstruktur dan program piranti lunaknya maupun proyek-proyek yang memerlukan dukungan komunikasi tidak menemui sasaran. Adanya potensi komunikasi yang dapat digunakan untuk memajukan peradaban umat manusia, dan Kemungkinan di masa depan teknologi komunikasi dan informasi dapat disalahgunakan untuk hal-hal negative, misalnya tindak criminal penipuan (cyber crime), teroris, pemerasan, judi, dan semacamnya.

Sebuah negara perlu membuat kebijaksanaan komunikasi dalam bentuk tertulis, apakah itu berupa undang-undang atau peraturan pemerintah dengan tujuan (Cangara, 2013:13) sebagai berikut: Untuk mencapai suatu iklim kesamaan semangat (spirit) pada usaha-usaha yang dilakukan oleh negara-negara sedang berkembang, maupun melalui mitra kerja dengan negara-negara maju dalam konteks kerja sama antar dua negara (bilateral) atau lebih (multilateral); Mengoptimalkan pendayagunaan sumber daya komunikasi untuk mendorong terjadinya peningkatan kesejahteraan bangsa secara terencana dan sistematis; Agar infomasi yang dikemas dan disebarluaskan relevan dengan kehidupan sehari-hari bagi pihak yang memerlukan, serta memberi motivasi kepada masayarakat untuk berperan serta dalam kegiatan kemasyarakatan; Membantu dalam kordinasi kerja antarlembaga, organisasi pemerintah, dan swasta dalam processing dan penyebarluasan infomasi, serta memberi kemungkinan fasilitas kearah terciptanya partisipasi masyarakat; Memformulasi kebijakan komunikasi dengan mengikutsertakan semua lembaga yang berkepentingan, memperkenalkan sektorsektor pembangunan yang digerakkan oleh aktivitas komunikasi, serta berusaha membantu mengurangi duplikasi kerja yang tidak perlu dengan menghindari terjadinya pengulangan dan penghamburan sumber daya yang terbatas.

Sistem berita internasional yang melebar luas merupakan bentuk perkembagan media berita Barat, khususnya yang terdapat di Inggris, Amerika, dan Perancis. Sistem berita dunia muncul karena masyarakat di negara Barat yang demokratis membutuhkan berita dunia, sehingga agen-agen berita dan agen surat kabar yang besar, serta ornganisasi penyiaran (radio dan televisi) saling bekerjasama, sekaligus bersaing untuk memuaskan kebutuhan orang banyak. Redaksi dan koresponden yang bekerja untuk organisasi agen berita yang bebas telah mengembangkan tradisi dan pola penyediaan berita dunia yang nyaris serempak, sehingga semua orang dimana pun ia berada dapat menerima informasi dengan baik dan dapat menyambungsiarkan berita (Shoelhi, 2014: 143).

Sistem berita internasional tersebut menjadi arus infomasi dan pertukaran berita yang ada di dunia. Ada beberapa surat kabar dan organisasi penyiaran yang melaporkan berita yang mereka peroleh dari agen pelayanan berita yang bersifat global. Mereka adalah Associated Press (AP) berasal dari Amerika, United Press International (UPI) juga dari Amerika, Agence France Press (AFP) berasal dari 
Prancis, Reuters berasal dari Inggris, dan TASS yang berasal dari Rusia. Lima organisasi berita dunia inilah yang menyalurkan dan menyiarkan berita dari semua bagian dunia kehampir seluruh kawasan dunia lainnya.

Sistem informasi internasional sedang bergerak dengan cepat kearah kondisi yang bersifat teoritis di mana sistem ini mampu mengirim informasi ke mana pun dalam waktu yang sesingkat mungkin (Manik, dkk (ed), 1993:58).

Dari beberapa pernyataan di atas jelasalah bahwa pengaliran berita internasional dewasa ini telah dikuasai oleh kantor-kantor berita negara-negara Barat terutama Amerika, Inggris, Prancis, dan Rusia. Kantor-kantor berita internasional tersebut yaitu AP, UPI, Reuters, AFP, dan TASS tetap menjadi sumber utama berita internasional terutama bagi negara-negara Timur.

Kantor-kantor berita internasional itu bergerak di atas dasar dan tujuan ekonomi yang memandang bahwa kepentingan konsumen mesti diutamakan. Kecenderungan yang demikian membuat mereka meliput dan menyebarkan berita yang sesuai dengan keinginginan konsumen, sehingga sering tidak sesuai dengan ideologi dan kebijaksanaan negara yang menjadi objek pemberitaan (Kholil, 2007: 83).

Dalam bukunya "Perencanaan dan Strategi Komunikasi”, Hafied Cangara yang merupakan guru besar di bidang ilmu komunikasi menyatakan bahwa adanya ketidakseimbangan tentang pengaliran berita dan informasi di dunia khususnya untuk negara-negara yang sedang berkembang.
Ketika itu negara-negara yang sedang berkembang yang dimotori oleh Perdana Menteri Indira Gandhi mengeluhkan adanya ketidaksemibangan informasi di dunia akibat mengalirnya informasi (information low) dengan tidak berkadilan dari negara-negara maju yang memiliki kekuatan teknologi komunikasi yang lebih canggih, ke negara-negara sedang berkembang yang kurang mampu membeli tekonologi infomasi (Cangara, 2013:5).

Ketidakseimbangan informasi ini didukung oleh hasil hasil riset Dr. Gebner (Dean, Annenberg School of Communication) terhadap isi enam puluh surat kabar yang terbit di Sembilan negara, yakni tiga negara kapitalis (Amerika Serikat, Inggris, dan Jerman Barat), tiga negara sosialis (Uni Soviet = sekarang Rusia, Hongaria, Cekoslawakia), dan tiga negara sedang berkembang (India, Filipina, dan Ghana). Dari hasil analisis ke-60 surat kabar tersebut menunjukkan bahwa surat-surat kabar yang terbit di negara-negara kapitalis dan negara-negara sosialis terlalu sedikit mengekspos tentang berita-berita di negara berkembang. Kalau toh surat kabar itu memberitakan, maka cenderung hanya hal-hal yang berkaitan dengan kerusuhan dan kemiskinan (Cangara, 2013: 5).

Menurut John C. Merriel, perbedaan itu sebenarnya bersumber dari perbedaan konsep yang digunakan oleh masingmasing negara. Daslam konteks kebebasan arus informasi, negara-negara maju (Barat) menilai informasi boleh bebas masuk ke negara lain. Dengan demikian bebas memberitakan apa saja, sementara negara-negara sedang berkembang (Timur) menganggap kebebasan arus 
informasi

menuntut

adanya

keseimbangan, artinya jika informasi negara maju bebas masuk ke negara sedang berkembang, maka seharusnya informasi dari negara sedang berkembang juga bisa bebas masuk ke negara-negara maju. Demikian juga isi informasi tidak seharusnya identik dengan kemiskinan dan kerusuhan, melainkan juga hal-hal yang positif sesuai dengan tahap perkembangannya (Cangara, 2013: 6).

Keluhan dari Indira Gandi ini mendapatkan dukungan luas dari negaranegara sedang berkembang yang merasa negaranya menjadi sasaran penjajahan terutama di bidang informasi, ekonomi, dan ideology. Kontroversial ini kemudaian dimanfaatkan oleh negara-negara sedang berkembang untuk menyerang negaranegara maju melalui UNESCO (United Nations Educational Scienticic and Cultural Organization).

Mengingat masalah-masalah komunikasi yang muncul dalam dekade 1970-an makin menggelisahkan sejumlah pakar dan para pemimpin negara-negara sedang berkembang, maka UNESCO mulai mengambil inisiatif untuk melakukan pertemuan lanjutan guna membicarakan pentingnya kebijakan dan perencanaan komunikasi diformulasikan kembali. Untuk itu, secara berturut-turut dilakukan pertemuan yang berlangsung (Cangara, 2013:7-8) di: 1) Pertemuan Paris, 1972, membicarakan isu-isu kunci yang erat hubungannya dengan kebijaksanaan dan perencanaan komunikasi, dan pentingnya dilakukan riset di dalam memformulasikan sistem komunikasi masing-masing negara. 2) Pertemuan Paris, 1974, pertemuan ini membicarakan aspek-aspek perencanaan dan manajemen terhadap proyek-proyek komunikasi yang akan dilakasanakan, dan pengembangan proyek-proyek komunikasi yang sedang berjalan di berbagai negara. 3) Pertemuan Kuala Lumpur, 1974, membicarakan tentang pentingnya pendidikan dan pelatihan dalam rangka peningkatan kemampuan para pekerja komunikasi. Pertemuan di Kuala Lumpur juga membicarakan pedoman-pedoman dasar perencanaan komunikasi dan peranan tenaga-tenaga perencana komunikasi, serta membicarakan kemungkinan pelaksanaan pendidikan dan pelatihan di bidang komunikasi untuk tingkat nasional, regional, dan internasional.

Pada tahun 1981, East West Communication Intitute dan University of Hawai, juga melakukan seminar kebijaksanaan komunikasi untuk pembangunan pedesaan di Thailand.

Pada tahun 1984 di Solo, Indonesia melakukan Seminar Internasional Pemerataan Satelit Komunikasi yang dilakukan oleh Ikatan Sarjana Komunikasi Indonesia (ISKI) yang dihadiri oleh para pakar dan praktisi komunikasi dari Jepang, Thailand, Filipina, Australia, Singapura, dan Indonesia sendiri sebagai tuan rumah.

Dari berbagai pertemuan yang dilaksanakan oleh UNESCO di bidang komunikasi, akhirnya diputuskan agar setiap negara anggota kembali menyusun dan memantapkan kembali kebijakan dan perencanaan komunikasinya dalam menangani pengelolaan infrastruktur, sumber daya, maupun program-program komunikasi di negara-negara masing (Cangara, 2013: 9).

Yang menjadi landasan dasar komunikasi internasional Indonesia lainnya yaitu terdapat pada Pancasila sila 
kedua, yaitu "Kemanusiaan yang Adil dan Beradab", yang mengandung unsur bahwa bangsa Indonesia merupakan dirinya bagian dari umat manusia di dunia. Oleh karena itu, dikembangkan sikap hormat menghormati dan bekerja sama dengan bangsa lain.

Dasar hukum kebijakan komunikasi internasional Indonesia juga tergambarkan secara jelas di dalam Pembukaan Undang-Undang Dasar 1945 alinea I dan alinea IV. Alinea I menyatakan bahwa ... "kemerdekaan ialah hak segala bangsa dan oleh sebab itu maka penjajahan di atas dunia harus dihapuskan karena tidak sesuai dengan peri kemanusiaan dan peri keadilan".

Selanjutnya pada alinea IV dinyatakan bahwa ... "dan ikut melaksanakan ketertiban dunia berdasarkan kemerdekaan, perdamaian abadi dan keadilan sosial" ... Dari dua kutipan UUD 1945 tersebut, jelaslah bahwa kebijakan komunikasi internasional Indonesia mempunyai landasan atau dasar hukum yang sangat kuat, karena diatur di dalam Pembukaan UUD 1945.

Landasan dasar komunikasi internasiona Indonesia, juga terdapat dalam ketetapan MPR No. IV/MPR/1999 tentang GBHN, Bab IV Arah Kebijakan, huruf $\mathrm{C}$ angka 2 tentang Hubungan Luar Negeri, dirumuskan hal-hal sebagai berikut:

Menegaskan arah politik luar negeri Indonesia yang bebas aktif dan berorientasi pada kepentingan nasional, menitik beratkan pada solidaritas antar negara berkembang, mendukung perjuangan kemerdekaan bangsa-bangsa, menolak penjajahan dalam segala bentuk, serta meningkatkan kemandirian bangsa dan kerjasama internasional bagi kesejahteraan rakyat.

Dalam melakukan perjanjian dan kerjasama internasional yang menyangkut kepentingan dan hajat hidup rakyat banyak harus dengan persetujuan lembaga perwakilan rakyat.

Meningkatkan kualitas dan kinerja aparatur luar negeri agar mampu melakukan diplomasi pro-aktif dalam segala bidang untuk membangun citra positif Indonesia di dunia internasional, memberikan perlindungan dan pembelaan terhadap warga negara dan kepentingan Indonesia, serta memanfaatkan setiap peluang positif bagi kepentingan nasional.

Meningkatkan kualitas diplomasi guna mempercepat pemulihan ekonomi dan pembangunan nasional, melalui kerjasama ekonomi regional maupun internasional dalam rangka stabilitas, kerjasama dan pembangunan kawasan.

Meningkatkan kesiapan Indonesia dalam segala bidang untuk menghadapi perdagangan bebas, terutama dalam menyongsong pemberlakuan AFTA, APEC dan WTO.

Memperluas perjanjian ekstradisi dengan negaranegara sahabat serta memperlancar prosedur diplomatik dalam upaya melaksanakan ekstradisi bagi penyelesaian perkara pidana.

Meningkatkan kerjasama dalam segala bidang dengan negara tetangga yang berbatasan langsung dan kerjasama kawasan ASEAN untuk memelihara stabilitas, pembangunan dan kesejahteraan (https://niajpnaw2612.wordpress.com/pen didikan/politik-luar-negeri-bebas-aktifrepublik-indonesia"). 


\section{PEMBAHASAN}

Pada tahun 1960, hubungan internasional yang pada awal kemunculannya hanya bergerak di bidang ekonomi, maka hubungan internasional mulai merembet ke bidang-bidang lainya diantaranya adalah di bidang politik. Keterlibatan Indonesia dalam hubungan internasional dimulai sejak diterimanya Indonesia menjadi anggota PBB yaitu pada tanggal 28 September 1950. Walaupun Indonesia sempat keluar dari anggota PBB pada tahun 1965, tetapi pada tanggal 28 September 1966 Indonesia diteima lagi menjadi anggota PBB.

Pada tanggal 8 agustus 1967, Indonesia resmi bergabung dengan organisasi ASEAN (Associaton of South East Asian Nation). Tujuan dibentuk ASEAN ini adalah membentuk organisasi kerjasama antar negara-negara Asia Tenggara yang tidak bersifat politis dan militer.

Bagi negara-negara tetangga, keikutsertakan Indonesia di ASEAN mempunyai arti politik-keamanan yang sangat penting. Terutama bagi Malaysia, Singapura dan Brunei yang pernah menjadi sasaran konfrontasi dan dilihatnya sebagai ambisi territorial (Maswadi Rauf dan Mappa Nasrun (Ed), 1993:273). Di samping keterlibatan Indonesia dalam kegiatan-kegiatan pada organisasasi PBB dan ASEAN, Indonesia juga terlibat dalam kegiatan-kegiatan internasional lainya seperti Non-Blok, OKI, Kelompok 77, Tata Ekonomi Dunia Baru, APEC, dan lain-lain.

Selain yang penulis sebutkan di atas, pelaksanaan dan implikasi Indonesia dalam hubungan internasional dapat kita lihat salah satunya yaitu ketika Indonesia berhasil menggelar "Global Inter Media Dialogue". "Global Inter Media Dialogue", adalah dialog antar media dari berbagai negara untuk membahas peradaban, budaya, dan agama. Forum tersebut digelar atas ide dan gagasan presiden Susilo Bambang Yudoyono yang mengamati bahwa ada jurang persepsi yang menganga antara media di Barat dan di dunai Islam. Banyak media Barat tidak mengerti Islam sehingga dalam meliput berita kurang peka terhadap isu-isu agama atau budaya Islam.

Forum "Global Inter Media Dialogue" ini pertama kali dilaksanakan pada tanggal 1 September 2006, di Bali dengan menjadikan Norewgia sebagai mitra dari negara Barat untuk mendukung forum ini. Forum ini dihadiri oleh 70 tokoh media terkemuka dari 53 negara -dari Timur Tengah, Eropa, Amerika, Asia, dan Amarika Latin. Dalam forum ini Presiden SBY menyampaikan yang intinya yaitu menyampaikan kegundahan yang dirasakan umat Islam terhadap Barat. Masyarakat muslim di dunia tidak ingin mendapatkan perlakuan khusus, mereka hanya ingin perlakuan yang sama seperti diberikan kepada kelompok agama lain.

Dilihat dari sudut diplomasi, pelaksanaan dan implikasi Indonesia dalam hubungan internasional juga telah mencapai sejumlah babak keberhasilan diplomasi yang layak dicatat, antara lain sebagai berikut: Menyelenggarakan KAA di Bandung pada tahun 1955; Menyelenggarakan KTT Non-Blok pertama di Beogard, tahun 1961; Peran kepeloporan dalam rangka ASEAN, ARF, forum APEC, dan forum ASEM; Sebagai juru bicara dan juru runding utama bagi G77; Memperjuangkan lahirnya resolusi 
majelis umum PBB; Peran fasilitator dan pemrakarsa dalam penyelesaian konflik di Kamboja, Filipina Selatan dan Laut Cina Selatan; Berperan di sembilan organ penting PBB; dan lain sebagainya.

Mohammad Shoelhi dalam bukunya "Diplomasi Praktik Komunikasi Internasional" menyatakan bahwa dalam menjalin kerjasama internasional, Indonesia selalu menekankan pada kerja sama konkret di berbagai bidang yang berkaitan dengan kepentingan nasional, diantaranya: Kerja sama pertahanan a.l. dengan Rusia, India, China, Perancis, Australia; Kerja sama perdangangan a.l. dengan Amerika Serikat, Jepang, China, Rusia, dan Korea Selatan; Kerja sama energi dengan Amerika Serikat, China, Rusia, Korea Selatan; Kerja sama pendidikan dengan Amerika Serikat, Australia; Kerja sama antikorupsi dalam kerangka APEC; Kerja sama antiterorisme dengan Amerika Serikat, Australia, Inggris, Filipina, Malaysia, Singapura; Kerja sama iptek dengan India, Amerika Serikat, China, Korea Selatan; Kerja sama TKI dengan Malaysia, Korea Selatan, Timur Tengah; Kerja sama interfaith dengan Inggris; Kerja sama intermedia dengan Norwegia; Kerja sama perbatasan dengan Timor Leste, Filipina, PNG, Malaysia; Kerja sama turisme dengan China, Singapura, Malaysia, Thailand; Kerja sama olahraga dengan Kuba.

Pada bidang Telekomunikasi dan Infomatika (TIK), Indonesia juga terlibat dalam menyelesaikan masalah pada organisasi Internastional

Telecommunications Union (ITU) yang berada di bawah naungan PBB. Arnold Ph. Djiwatampu dalam bukunya "Strategi Perjuangan Internasional Komunikasi Misi
Mustahil Menjadi Mungkin" menyebutkan beberapa keterlibatan Indonesia dalam penyelesaian masalah ITU (Djiwatampu, 2015: 127), diantaranya adalah: Mengamankan orbit satelit palapa; Ikut terjun dalam perjuangan alokasi pita lebar satelit Non-GSO, TELEDESIC, sebuah satelit milik Amerika Serikat yang ditentang oleh Eropa; Mengangkat sistem satelit LEO kecil; Ikut berperan serta dalam menyelesaikan penentangan Prancis terhadap penempatan satelit Iran Zohreh; Membantu negara-negara Afika ITSO (INTELSAT) sebagai common Heritage.

Dari beberapa uraian di atas mengenai peran Indonesia pada pelaksanaan dan implikasinya dalam hubungan internasional, dapat disimpulkan bahwa peran Indonesia pada hubungan Internasional sangatlah besar. Hal ini dapat kita lihat dari banyaknya Indonesia terlibat pada hubungan internasional, baik melakukan hubungan kerja sama di bidang politik, pendidikan, iptek, dan lain-lain yang dilakukan dengan negara-negara dan organisasi-organisasi internasional sesuai dengan apa yang penulis kemukakan di atas.

Banyaknya organisasi internasional yang dikuti Indonesia tak terlepas dari kebijakan politik luar negeri Indonesia. Politik luar negeri Indonesia adalah bebas dan aktif. Bebas, bahwa Indonesia tidak memihak pada kekuatan-kekuatan yang tidak sesuai dengan kepribadian bangsa sebagaimana tercermin dalam Pancasila. Aktif, bahwa dalam menjalankan kebijakan luar negerinya, Indonesia tidak bersikap pasif atas berbagai kejadian internasional, melainkan bersikaf aktif. Juga aktif dalam mendukung usaha-usaha 
yang diarahkan bagi terciptanya masyarakat dunia yang damai, aman dan tentram (Djamaluddin Manik dkk (ed), 1993: 70).

Struktur kebijakan pemerintah terhadap teknologi informasi berdasarkan Departemen Komunikasi dan Informasi (Depkominfo) (Rapat Kerja Dekomimfo, 3 Maret 2006). Visimya adalah terwujudnya masyarakat infomasi yang sejahtera melalui penyelenggaraan komunikasi dan informatika yang efektif dan efisien dalam kerangka Negara Kesatuan Republik Indonesia.

Misinya adalah meningkatkan kapasistas layanan informasi dan pemberdayaan potensi masyarakat dalam rangka mewujudkan masayarakat berbudaya infomasi; Meningkatkan daya jangkau infrastruktur pos, komunikasi, dan informatika untuk memperluas aksesibilitas masyarakat terhadap informasi dalam rangka mengurangi kesenjangan informasi; Mendorong peningkatan aplikasi layanan publik dan industry aplikasi telematika dalam rangka meningkatkan nilai tambah layanan dan industry aplikasi; Mengembangkan standarisasi dan sertifikasi dalam rangka menciptakan iklim usaha yang konstruktif dan kondunsif di bidang industry komunikasi dan informatika; Meningkatkan kerjasama dan kemitraan serta pemberdayaan lembaga komunikasi dan informatika pemerintah dan masyarakat; Mendorong peranan media massa dalam rangka meningkatkan informasi yang beretika dan bertanggung jawab serta memberikan nilai tambah pembangunan bangsa; Meningkatkan kapasitas SDM bidang komunikasi dan informatika dalam rangka meningkatkan literasi dan profesionalisme; Meningktkan kualitas dan kapasitas litbang dan industri dalam rangka menciptkan kemandirian dan daya saing bidang telekomunikasi, komunikasi dan informatika; Mendorong pemerataan dan penyebarluasan jangkauan informasi public kepada masyarakat; Meningkatkan kualitas pelayanan public dalam kerangka peningkatan penyebaran dan pemerataan informasi; Meningkatkan peran serta aktif Indonesia dalam berbagai forum internasional di bidang komunikasi dan informatika dalam rangka meningkatkan citra positif bangsa dan Negara; Meningkatkan kualitas pengawasan menuju terselenggaranya kepemerintahan yang baik (good governance).

Program yang dicanangkan adalah: program peningkatan komitmen persatuan dan kesatuan nasional; Program peningkatan kualitas pelayanan informasi public; Program penerapan kepemerintahan yang baik; Program peningkatan pengawasan dan akuntabilitas aparatur Negara; Program penataan kelembagaan dan ketatalaksanaan; Program pengelolaan sumber daya manusia aparatur; Program penyelengaraan pimpinan kenegaraan dan pemerintahan; Progam peningkatan sarana dan prasarana aparatur Negara; Program peningkatan kualitas pelayanan public; Program penyempurnaan dan penguatan kelembagaan demokrasi; Program pengembangan komunikasi, informasi, dan media massa; Program penyelesaian restrukturisasi pos dan telematika; Program pengembangan, pemerataan, dan peningkatan kualitas sarana, prasarana pos, dan telematika; Program penguasaan serta pengembangan 
aplikasi dan teknologi informasi dan komunikasi; Program pengembangan wilayah tertinggal; Program pengembangan wilayah perbatasan.

Kebijakan yang dilakukan meliputi pengembangan di bidang: Pos dan telekomunikasi (regulasi, universal service obligations, public service obligation); Aplikasi telematika (regulasi, community accsess point, one school one computer laboratium); Sarana komunikasi dan desiminasi informasi (regulasi, desiminasi); Pelayanan informasi publik (Kominfo news room).

Program-program tersebut merupakan bagian yang tidak terpisahkan dari komitmen Indonesia terhadap perjanjian internasional, salah satunya di World Summit on Information Society (WSIS).

Berikut ini plan of action: Menghubungkan seluruh desa dengan information communication technology system (ICTs) dan membangung community access points (C ); Menghubungkan seluruh universitas, dan sekolah dengan ICTs; Menghubungkan seluruh pusat ilmu pengetahuan dan pusat riset denga ICTs; Menghubungkan perpustakaan umum, pusat kebudayaan, museum, kantor pos, arsip dengan ICTs; Menghubungkan pusat-pusat layanan kesehatan dan rumah sakit denga ICTs; Menghubungkan seluruh pemerintah (pusat dan daerah), seluruh institusi pemerintah, membangun websites dan $e$ mail address; Menyesuaikan kurikulum SMP dan SMA (sesuai dengan kondisi nasional) untuk menghadapi tantangan masyarakat informasi; Memastikan seluruh penduduk dunia telah dapat mengakses layanan televisi dan radio;
Mendorong pengembangan konten, dan memfasilitasi penggunaan ragam bahasa (world langunges) di internet; Memastikan lebih dari setengah penduduk dunia dapat mengakses ICTs sesuai dengan kemampuan mereka.

Permasalahan/kelemahan adalah belum sinkronnya pelaksanaan program dan kegiatan bidang komunikasi dan informatika antara instansi pusat, daerah, da Departemen Komunikasi dan Infomatika; Adanya "mata rantai" yang terputus dalam pelaksanaan koordinasi kelembagaan dan fungsional antara pusat dan daerah; Rendahnya kualitas SDM di bidang komunikasi dan informatika; Masih banyaknya daerah "blank spot" dan wilayah perbatasan yang belum terjangkau pembangunan dibidang komunikasi dan informatika; Belum tertangani secara optimal pengelolaan komunikasi dan informasi di daerah konflik dan rawan konflik; Masih minimnya anggaran yang dikelola Departemen Komunikasi dan Informatika.

Solusinya adalah perlu harmonisasi dan penjabaran seluruh program, dan kegiatan Depkominfo dengan rencana pembangunan jangka panjang (RPJP), rencana pembangunan jangka menengan (RPJM), rencana strategis (RENSTRA), dan kesepakatan-kesepakatan The World Summit on the Information Society (WSIS); Menciptakan progam yang beimbang antara pembangunan dan pemanfaatan ICT, baik sebagai tools maupun sebagai industri, dengan desiminasi informasi yang intensif dan cakupan yang luas; Memfokuskan program dan kegiatan Depkominfo pada upaya untuk merealisasikan pencapaian target-target; Meningkatkan koordianasi baik vertical 
maupun horizontal dengan institusi terkait baik di pusat maupun daerah untuk menghindari duplikasi dalam penyusunan program dan kegiatan sehingga sumber daya yang ada dapat teralokasikan secara baik, dan memperoleh dukungan yang luas terhadap implementasi berbagai programprogram dan kegiatan Depkominfo; Menyongsong masa depan, diharapkan Depkominfo dapat memaksimalkan peran strategis komunikasi dan informatika untuk mewujudkan peradaban masyarakat berbasis pengetahuan; berperan sebagai faktor pendukung dan motor penggerak pembangunan Indonesia di berbagai bidang; dan berperan sebagai medium penumbuhkembangan rasa percaya masyarakat pada proses pembangunan yang terus berlangsung; Dengan dukungan SDM yang terampil dan memiliki kompetensi standar internasional, diyakini upaya Depkominfo untuk mendukung pembangunan di berbagai sektor dalam upaya mewujudkan masyarakat informasi Indonesia yang maju, aman, berbudaya, dan berbasis pengetahuan dapat terwujud (Liliweri, 2014: 461).

\section{SIMPULAN}

Dasar kebijakan komunikasi internasional Indonesia dimulai dari Perdana Menteri Indira Gandhi yang mengeluhkan adanya ketidaksemibangan informasi di dunia terhadap negaranegara berkembang yang akhirnya di respon oleh negara-negara berkembang lainnya termasuk Indonesia. Dasar kebijakan komunikasi internasional Indonesia lainnya yaitu Pancasila sila kedua, UUD 1945 (Alinea I dan IV) dan batang tubuh (pasal 11 dan 13). Kemudian
Ketetapan MPR, yaitu GBHN dalam bidang hubungan luar negeri, kebijaksanaan Presiden, yang dituangkan dalam Keppres. dan kebijaksanaan/peraturan yang dikeluarkan oleh Menteri luar negeri.

\section{DAFTAR PUSTAKA}

Cangara, H., (2013). Perencanaan \& Strategi Komunikasi. Jakarta: PT RajaGrafindo Persada.

Djiwatampu, A., (2015). Strategi Perjuangan Internasional Komunikasi Misi Mustahil Menjadi Mungkin. Jakarta: PT Grasindo.

Effendi, O.U., (1999). Hubungan Masyarakat Suatu Studi Komunikologis. Bandung: Remaja Rosdakarya (2003). Ilmu, Teori dan Filsafat Komunikasi. Bandung: Citra Aditya Bakti.

Kholil, S., (Ed). (2011). Teori Komunikasi Masa. Bandung: Ciptapustaka Media Perintis. (2007). Komunikasi Islami. Bandung: Ciptapusaka Media.

Liliweri, A.. (2014). Sosiologi $\mathcal{E}$ Komunikasi Organisasi. Jakarta: Bumi Aksara.

Manik, D.D., dkk (ed). (1993). Komunikasi Internasional. Bandung: PT Remaja Rosdakarya.

Mulyana, D., (2014). Komunikasi Politik Politik Komunikasi. Bandung: PT Remaja Rosdakarya.

Rauf, M., dan Mappa N., (Ed). (1993). Indonesia dan Komunikasi Politik. Jakarta: PT Gramedia Pustaka Utama.

Rudy, T.M., (2005). Komunikasi \& Hubungan Masyarakat Internasional. Bandung: PT Refika Aditama.

Sen, K., dan David T.H., (2001). Media, Budaya Dan Politik Di Indonesia. Jakarta: PT Sembrani Aksara Nusantara.

Shoelhi, M., (2011). Diplomasi Praktik Komunikasi Internasional. Bandung: Simbiosa Rekatama Media.

. (2014). Komunikasi Internasional Perspektif Jurnalistik. Bandung: Simbiosa Rekatama Media. (2012). Propaganda Dalam Komunikasi Internasional. Bandung: Simbiosa Rekatama Media. 